\title{
VALIDATION OF THE DEARDORFF MODEL FOR ESTIMATING ENERGY BALANCE COMPONENTS FOR A SUGARCANE CROP
}

\author{
Glauco de Souza Rolim; João Francisco Escobedo; Amauri Pereira Oliveira² \\ ${ }^{1}$ UNESP/FCA - Depto. de Irrigação e Drenagem, C.P. 237 - 18610-307 - Botucatu, SP - Brasil. \\ ${ }^{2}$ USP/IAG - Depto. de Ciências Atmosféricas, C.P. 66318 - 05508-900 - São Paulo, SP - Brasil. \\ *Corresponding author <rolim@iac.sp.gov.br>
}

\begin{abstract}
The quantification of the available energy in the environment is important because it determines photosynthesis, evapotranspiration and, therefore, the final yield of crops. Instruments for measuring the energy balance are costly and indirect estimation alternatives are desirable. This study assessed the Deardorff's model performance during a cycle of a sugarcane crop in Piracicaba, State of São Paulo, Brazil, in comparison to the aerodynamic method. This mechanistic model simulates the energy fluxes (sensible, latent heat and net radiation) at three levels (atmosphere, canopy and soil) using only air temperature, relative humidity and wind speed measured at a reference level above the canopy, crop leaf area index, and some pre-calibrated parameters (canopy albedo, soil emissivity, atmospheric transmissivity and hydrological characteristics of the soil). The analysis was made for different time scales, insolation conditions and seasons (spring, summer and autumn). Analyzing all data of 15 minute intervals, the model presented good performance for net radiation simulation in different insolations and seasons. The latent heat flux in the atmosphere and the sensible heat flux in the atmosphere did not present differences in comparison to data from the aerodynamic method during the autumn. The sensible heat flux in the soil was poorly simulated by the model due to the poor performance of the soil water balance method. The Deardorff's model improved in general the flux simulations in comparison to the aerodynamic method when more insolation was available in the environment.
\end{abstract}

Key words: energy budget, net radiation, latent heat flux, sensible heat flux, microclimate

\section{VALIDAÇÃO DO MODELO DE DEARDORFF PARACÁLCULO DO BALANÇO DE ENERGIA DURANTE UM CICLO DE CANA-DE-AÇÚCAR}

RESUMO: A quantificação da energia disponível no ambiente é importante porque ela afeta a fotossíntese, a evapotranspiração e conseqüentemente a produtividade final dos cultivos. Instrumentos para medidas de balanço de energia são caros e alternativas para estimações são desejáveis. O presente trabalho procura avaliar a performance do modelo de Deardorff (1978) ao longo do desenvolvimento de uma cultura de cana-de-açúcar em Piracicaba, SP, Brasil, em comparação ao método aerodinâmico. Este modelo mecanístico simula os fluxos energéticos (calor sensível, latente e saldo de radiação) em três níveis: a atmosfera, o dossel vegetativo e o solo, usando somente a temperatura do ar, umidade relativa e velocidade do vento medidos num nível de referência acima do dossel, o índice de área foliar e alguns parâmetros previamente calibrados (albedo do dossel, emissividade do solo e a transmissividade atmosférica e características hidrológicas do solo). As análises dos resultados foram feitas em diversas escalas de tempo, condições de insolação, nas diferentes estações do ano (primavera, verão, outono). Analisando todos os dados de 15 minutos, o modelo apresentou boa performance na simulação de radiação líquida em diferentes condições de insolação e estações do ano. O fluxo de calor latente e o fluxo de calor sensível na atmosfera não apresentaram diferenças em comparação ao método aerodinâmico no outono. O calor sensível no solo foi pobremente simulado pelo modelo devido à baixa capacidade de estimação do balanço hídrico do solo. Geralmente as estimações pelo modelo de Deardorff foram melhoradas quando mais insolação era disponível no ambiente.

Palavras-chave: balanço energético, radiação líquida, fluxo de calor latente, fluxo de calor sensível, microclima 


\section{INTRODUCTION}

Studies on energy balance of agricultural areas allow the understanding of energy change processes in relation to evapotranspiration and photosynthesis, which directly affect the biomass accumulation and agricultural yield. Several studies can be cited, as those related to evapotranspiration estimations (Villa Nova et al., 2007), to leaf wetness duration and its consequences on pathogen infection processes (Marta et al., 2007), and to the development of mechanistic crop growth models (Pauwels et al., 2007), among others.

Several methods are available to estimate the energy balance of the environment, also when there is data limitation. The models presented by Shuttleworth \& Wallace (1985), Zapata \& MartinezCob (2002) and Hemakumara et al. (2003) are examples of them. At the mesoclimatic scale, the Deardorff's (1978) model has been used with success to simulate energy fluxes (Soares et al., 1996; Targino \& Soares, 2002). Vogel et al. (1995) observed that Deardorff's (1978) model presented a better performance simulating the sensible heat flux (in air and soil) than other models, when applied to vegetated surfaces.

At the microclimatic scale, few agricultural studies can be found using the Deardorff (1978) model. Tattari et al. (1995) tested Deardorff's (1978) model and compared it to the Bowen's ratio method to estimate barley crop evapotranspiration, but the results were not very good due to problems with measurements made under adverse climatic conditions, such as high humidity, gusts of wind and rain. However, McCumber (1980) and Garret (1982) stated that among the methods found in the literature, the one proposed by Deardorff (1978) is the most efficient to estimate energy balances with quality and simplicity. Finally, Oliveira et al. (1999) working with maize and grass crops at Candiota, RS, Brazil, obtained good results in simulations of sensible and latent flux and net radiation.

The advantage of using the model proposed by Deardorff (1978) is the significant reduction of the number of instruments required to estimate the energy balance of a given crop, since it only requires air temperature, relative humidity, wind speed, leaf area index and some hydrological parameters of the soil. This study analyses the performance of Deardorff's (1978) model to estimate net radiation, latent heat flux, sensible heat flux in the atmosphere and in the soil, during a complete cycle of a sugarcane crop, in comparison to the aerodynamic method.

\section{MATERIALAND METHODS}

\section{Site descriptions and measurements}

The sugarcane cultivar IAC 87-3396 used in this study was sown on 12/08/2001 with 1 meter row spacing in the east-west orientation. The experimental field is characterized by a flat area of about $1 \mathrm{~km}^{2}$, located in Piracicaba, Sate of São Paulo, Brazil (22 $2^{\circ} 40^{\prime}$ S, 47 ${ }^{\circ} 38^{\prime} \mathrm{W}$ and altitude $514 \mathrm{~m}$ ). The meteorological data, were collected each second and integrated every 15 seconds, from 08/17/2001 to 05/31/2002 using a Campbell 21X datalogger and sensors previously calibrated. The sensors were mounted on a tower at the center of the area and the measurements were made at six levels: $5 \mathrm{~m}$ from the surface (rain); $2 \mathrm{~m}$ from the top of the canopy (temperature, relative humidity, wind speed, net radiation, global and reflected solar radiation); $3 / 4$ of canopy height (temperature, relative humidity and wind speed); on the soil surface (heat flux); in the soil, 5 and $20 \mathrm{~cm}$ below the surface (temperature and humidity). The levels: $2 \mathrm{~m}$ from the top of the canopy and $3 / 4$ of canopy height were adjusted monthly to follow crop growth. The $2 \mathrm{~m}$ level mentioned above, contains the necessary data for Deardorff's (1978) model inputs (temperature, relative humidity and wind speed) and the extra observations were necessary for model comparisons.

The sugarcane crop was chosen due to its great economic interest in State of São Paulo, besides its long cycle which makes possible performance analyses of the model during several seasons of the year.

\section{Determination of the energy balance components by the aerodynamic method}

The estimation of the energy balance components $(\mathrm{Rn}$ - Net radiation, LE - Latent heat flux, $\mathrm{H}$ sensible heat flux in the atmosphere and G- Sensible heat flux in the soil) by the aerodynamic method using data observed in the field was made to compare the simulated data obtained by the Deardorff's (1978) model.

From data obtained every 15 seconds the Richardson number (Ri) was calculated in order to compare the thermal forces responsible for the free convection, with the mechanical forces responsible for the forced convection. The Richardson number was calculated by the following equation:

$$
R i=\frac{g \cdot d \Theta / d z}{\Theta m \cdot(d u / d z)^{2}}
$$

where: $g$ is the gravitational acceleration $\left(9.8 \mathrm{~m} \mathrm{~s}^{-1}\right)$, $d \Theta / d z$ is the potential temperature gradient $\left(\mathrm{K} \mathrm{m}^{-1}\right), d u /$ $d z$ is the wind speed gradient $\left(\mathrm{s}^{-1}\right)$. The potential tem- 
perature is calculated by $Q=$ air temperature (K). $(1000 / 800)^{0.2857}$.

In order to estimate the effect of Ri on the turbulent diffusion coefficient $(\mathrm{Km})$, which makes possible to quantify the transport of atmospheric activity (sensible and latent heat flux) the function $\phi \mathrm{m}$ was calculated for the following cases: unstable conditions (when $\mathrm{Ri}<0)$ : $\phi \mathrm{m}=(1-16 . \mathrm{Ri})^{-0.25}$; stable conditions (when $\mathrm{Ri}>0$ ): $\phi \mathrm{m}=1+5 . \mathrm{Ri}$; and neutral conditions (when $\mathrm{Ri}=0$ ): $\phi \mathrm{m}=1$ given by:

The turbulent diffusion coefficient $(\mathrm{Km})$ is

$$
K m=k^{2} \cdot(z-d)^{2} \cdot \frac{d u}{d z \cdot \phi m^{2}}
$$

where: $\mathrm{k}$ is the von Karman constant $(=0.41)$, $\mathrm{z}$ the reference sensor height and $d$ is the zero place displacement (considered $3 / 4$ of the canopy height). The coefficient $\mathrm{Km}$ was used to estimate the sensible heat flux:

$$
H=-\rho \cdot C p \cdot K m \cdot \frac{d T}{d z}
$$

where: $\rho$ is air density $\left(=1,292 \mathrm{~kg} \mathrm{~m}^{-3}\right), \mathrm{Cp}$ the specific heat of dry air at constant pressure $(=1,005 \mathrm{~kJ}$ $\mathrm{kg}^{-1} \mathrm{~K}^{-1}$ ) and $\mathrm{dT} / \mathrm{dz}$ the temperature gradient between the two sensors.

The values of the sensible heat flux in the soil (G) and net radiation (Rn) were obtained directly from field measurements and when $\mathrm{H}$ was possible to be calculated, the latent heat flux value (LE) was obtained from:

$L E=R n-H-G$

\section{Deardorff's (1978) model}

The Deardorff's (1978) model comprises several stages, however some relevant aspects can be briefly described: the model considers that there is only one vegetation layer, whose thermal capacity is insignificant and characterized by a coefficient $\left(\sigma_{f}\right)$ that is associated with the degree to which the canopy prevents the shortwave radiation to reach the soil, which is calculated using the leaf area index (LAI). $\sigma_{\mathrm{f}}=0$ refers to absent vegetation cover and $\sigma_{\mathrm{f}}=1$ to complete vegetation cover (theoretical).

With the coefficient $\sigma_{\mathrm{f}}$ and considering the wind logarithmic profile, three heat transfer coefficients can be calculated for the following levels: bare soil surface $\left(\mathrm{C}_{\mathrm{H} 0}=\mathrm{k}^{2} \cdot \ln \left(\mathrm{z} / \mathrm{z}_{\mathrm{o}}\right)^{-2}\right.$, where $\mathrm{k}=0.4 ; \mathrm{z}=2$ $\mathrm{m}$ above the canopy and $\mathrm{z}_{\mathrm{o}}=$ roughness parameter); high immediately above the canopy top $\left(\mathrm{C}_{\mathrm{Hh}}=(1 /\right.$ $\left.\mathrm{k}) \cdot \ln \left[(\mathrm{z}-\mathrm{d}) / \mathrm{z}_{0} \mathrm{~h}\right]\right)$, where $\mathrm{d}=$ zero plane displacement $=3 / 4$. Canopy high; $\mathrm{z}_{0} \mathrm{~h}=($ canopy high $\left.-\mathrm{d}) / 3\right)$; soil surface $\left(\mathrm{C}_{\mathrm{Hg}}=\left(1-\sigma_{\mathrm{f}}\right) \cdot \mathrm{C}_{\mathrm{H} 0}+\sigma_{\mathrm{f}} \cdot \mathrm{C}_{\mathrm{Hh}}\right)$.
Using the coefficient $\mathrm{C}_{\mathrm{Hh}}$ at the reference level $\left(u_{a}\right)$, the mean speed inside the canopy $\left(u_{a f}\right)$ is calculated by:

$u_{a f}=0.38 s_{f} c_{H h}^{1 / 2} u_{a}+\left(1-s_{f}\right) u_{a}\left(\mathrm{~m} \mathrm{~s}^{-1}\right)$

where: $u_{a}$ is the wind speed $\left(\mathrm{m} \mathrm{s}^{-1}\right)$ measured at reference level

It was assumed that the inner part of the canopy presents average conditions between the atmosphere and the soil, thus the air temperature inside the vegetation $\left(T_{a f}\right)$ and the correspondent humidity $\left(q_{a f}\right)$ were calculated by the following equations:

$T_{a f}=\left(1-\sigma_{f}\right) T_{a}+\sigma_{f}\left(0.3 T_{a}+0.6 T_{f}+0.1 T_{g}\right)$

$q_{a f}=\left(1-\mathrm{s}_{f}\right) q_{a}+\sigma_{f}\left(0.3 q_{a}+0.6 q_{f}+0.1 q_{g}\right)\left(\mathrm{cm}^{3} \mathrm{~cm}^{-3}\right)$

where: $T_{f}=$ average leaf temperature, $T_{g}=$ soil surface temperature, $T_{a}=$ temperature at the reference level (measured) and $\mathrm{q}_{\mathrm{af}}, \mathrm{q}_{\mathrm{g}}, \mathrm{q}_{\mathrm{a}}$ and $\mathrm{q}_{\mathrm{f}}$ are analogous specific humidities.

In a simple way, $\mathrm{T}_{\mathrm{f}}$, and $\mathrm{q}_{\mathrm{f}}$ have been estimated from the energy balance at the level of a single leaf inside the canopy. This is an iterative calculation procedure that aims to minimize the differences in the following equation:

$$
\begin{aligned}
& R_{S h}^{\downarrow}+R_{L h}^{\downarrow}-R_{S h}^{\uparrow}-R_{L h}^{\uparrow}-\left(R_{S g}^{\downarrow}+R_{L g}^{\downarrow}-R_{S g}^{\uparrow}-R_{L g}^{\uparrow}\right)= \\
& =H_{s h}-H_{s g}+\lambda\left(E_{h}-E_{g}\right)
\end{aligned}
$$

where: $R_{S}, R_{L}, H_{s}$ and $E$ are short and long wave radiative fluxes, sensible heat flux and evapotranspiration, respectively, and $\mathrm{l}$ is the evaporation latent heat. The subscribed letters $h$ and g represent values at the canopy top and on the soil surface, respectively. Finally, the arrows indicate the radiative flux directions. When the Stefan-Boltzmann's equation is used in each side of the equation 8 and other changes mentioned by Deardorff (1978) are introduced, the result is equation 9, which must be solved to find the representative canopy leaf temperature:

$$
\begin{aligned}
& \sigma_{f}\left[\left(1-\alpha_{f}\right) R_{S h}^{\downarrow}+\varepsilon_{f} R_{L h}^{\downarrow}+\frac{\varepsilon_{f} \varepsilon_{g}}{\left(\varepsilon_{f}+\varepsilon_{g}-\varepsilon_{f} \varepsilon_{g}\right)} \sigma T_{g}^{4}-\right. \\
& \left.-\frac{\left(\varepsilon_{f}+2 \varepsilon_{g}-\varepsilon_{f} \varepsilon_{g}\right)}{\left(\varepsilon_{f}+\varepsilon_{g}-\varepsilon_{f} \varepsilon_{g}\right)} \varepsilon_{f} \sigma T_{f}^{4}\right]=H s_{f}+\lambda E_{f}
\end{aligned}
$$

where: $\alpha_{\mathrm{f}}$ and $\varepsilon_{\mathrm{f}}$ are the albedo and the foliage emissivity, $\varepsilon_{\mathrm{g}}$ is the soil emissivity and $\mathrm{s}$ is the Stefan-Boltzmann constant $\left(5.67 \times 10^{-8} \mathrm{~W} \mathrm{~m}^{-2} \mathrm{~K}^{-4}\right)$.

Another peculiarity of Deardorff's (1978) model is the use of the F-R method (Force Restore) proposed by Bhumralkar (1975) to calculate $\mathrm{T}_{\mathrm{g}}$. It consists in a resolution of an equation which depends on 
the energy flux sum in the atmosphere and contains a mechanism that causes an influence of the deep soil layers on the surface temperature. Thus, the soil is divided in two layers: a superficial one, for which the soil temperature is influenced by the daytime cycle, and a deep one, of infinite depth in which the temperature changes in an annual scale, as follows:

$\frac{\partial T_{g}}{\partial t}=-\frac{c_{1} H_{A}}{\rho_{s} c_{s} d_{1}}-c_{2} \frac{T g-T 2}{\tau_{1}}$

where: $T_{2}$ is the average temperature of the soil in the deep layer; $c_{1}$ and $c_{2}$ are dimensionless constants; $\rho_{s}$ is the soil density; $\mathrm{c}_{\mathrm{s}}$ the soil specific heat; $\mathrm{d}_{1}$ the soil depth under the influence of daytime cycle; and $\tau_{1}$ is the photoperiod; $\mathrm{H}_{\mathrm{A}}$ is the sum of the atmospheric fluxes at the surface as a result of the energy balance at the soil surface.

Finally, the Deardorff's (1978) model, besides temperature, relative humidity and wind speed data, requires some parameters that were previously calibrated (Table 1). Basically, the calibration of these parameters aimed to an approach between the measured and simulated data by the model, using the iterative method Simplex with initial values of $\varepsilon_{\mathrm{f}}=0.95$; $\varepsilon_{\mathrm{g}}=$ 0.95; $\alpha_{\mathrm{f}}=0.2$ according to results of Targino \& Soares (2002) and $\tau=0.7$. A total of 12 days were used for this process (4 days of each season with different insolation conditions), considering the available 249 days.

These parameters are similar to those found in literature, as Monteith \& Unsworth (1990), who related an emissivity for a sugarcane surface of $97.7 \pm$ $0.4 \%$. Gates (1980), on the other hand, found an albedo of 0.17 during the complete development of a given sugarcane crop. Finally, Unsworth \& Monteith (1972), who made atmospheric transmissivity measurements in England, obtained values of 0.95 for very clear days and 0.5 for days with too much pollution or for cloudy sky conditions.

The Deardorff's (1978) model also requires three soil hydrologic parameters: water contents at wiltting point $\left(\mathrm{w}_{\text {wilt }}\right)$, at field capacity $\left(\mathrm{W}_{\mathrm{k}}\right)$ and at saturation $\left(\mathrm{W}_{\max }\right)$. In relation to this a physico-hydric analysis of the soil was accomplished giving emphasis on the determination of the soil water characteris-

Table 1 - Calibrated dimensionless parameters used in the Deardorff's (1978) model: $\alpha_{\mathrm{f}}$ - canopy albedo, $\varepsilon_{\mathrm{g}}$ - soil emissivity, $\varepsilon_{\mathrm{f}}$ - canopy emissivity, and $\mathrm{t}$ atmospheric transmissivity.

\begin{tabular}{lccc}
\hline & $\alpha_{\mathrm{f}}$ & $\varepsilon_{\mathrm{g}}\left(=\varepsilon_{\mathrm{f}}\right)$ & $\tau$ \\
\hline Spring & 0.17 & 0.97 & 0.59 \\
Summer & 0.21 & 0.96 & 0.57 \\
Autumn & 0.20 & 0.98 & 0.58 \\
\hline
\end{tabular}

tic curve. The results were: $\mathrm{w}_{\text {wilt }}=0.15 ; \mathrm{W}_{\mathrm{k}}=0.21$; $\mathrm{W}_{\max }=0.32\left(\mathrm{~cm}^{3} \mathrm{~cm}^{-3}\right)$.

\section{Biometrical measurements of the sugarcane crop}

The parameters that affect the logarithmic wind profile above canopy, leaf area (LA) and average height of the canopy, were measured every 15 days from $08 / 17 / 2001$ to $05 / 30 / 2002$, considering five replications. The leaf area index (LAI) was determined by collecting and measuring leaves from a randomized area of $1 \mathrm{~m}^{2}$, using a paper guide with accuracy of $1 \mathrm{~mm}$.

\section{Evaluation of Deardorff's (1978) model}

The data simulated by the model (SIM): $\mathrm{T}_{\mathrm{af}}$, $\mathrm{u}_{\mathrm{a}}$, canopy relative humidity $\left(\mathrm{RH}_{\text {canopy }}\right), \mathrm{Rn}, \mathrm{LE}, \mathrm{H}, \mathrm{G}$, were compared to those calculated by the aerodynamic method (AERO) using the index of agreement $i_{d}$ suggested by Willmott (1981):

$$
i_{d}=1-\frac{\sum_{i=1}^{N}\left(P_{i}-O_{i}\right)^{2}}{\sum_{i=1}^{N}\left(\left|P_{i}-\bar{O}\right|+\left|O_{i}-\bar{O}\right|\right)^{2}}
$$

where: $i_{d}$ is dimensionless and ranges from 0 (zero) to 1 , considering that the value 1 indicates complete agreement between observed and estimated values; $P_{i}$ are SIM values; $\mathrm{O}_{i}$ are AERO values; $\bar{O}$ the mean of AERO values and $\mathrm{N}$ the number of observations.

\section{RESULTS AND DISCUSSION}

Meteorological elements inside the canopy were directly affected by crop development. The increase of the leaf area index and canopy height (Figure 3) affected the wind speed inside the canopy $\left(\mathrm{u}_{\mathrm{af}}\right)$, which was reduced in relation to the reference level (Figure 1C). Because of that, the difference $u_{r e f}-u_{a}$ was smaller during the spring than in the autumn. Figure $1 \mathrm{D}$ shows that soil temperature (5 and $20 \mathrm{~cm}$ ) was reduced during the crop growth.

The five-day moving average of $\mathrm{Rn}$ ranged from $500 \mathrm{~W} \mathrm{~m}^{-2}$ to $700 \mathrm{~W} \mathrm{~m}^{-2}$ from summer to spring and from $450 \mathrm{~W} \mathrm{~m}^{-2}$ to $600 \mathrm{~W} \mathrm{~m}^{-2}$ during autumn (Figure 2). The first summer weeks presented maximum values of $\mathrm{LE}$, up to $490 \mathrm{~W} \mathrm{~m}^{-2}$, whereas in middle of autumn they reached only $150 \mathrm{~W} \mathrm{~m}^{-2}$.

The maximum LAI and height found for sugarcane crop were 4.6 and $2.8 \mathrm{~m}$, respectively (Figure $3)$. These results also correspond to those found in the literature, e.g. Leme et al. (1984), who observed a maximum LAI of 4.5 for the sugarcane cultivar CB47-355, and Bull \& Glasziou (1975) and Machado et al. (1982) that also observed that the crop reached a maximum height of $2.6 \mathrm{~m}$. 

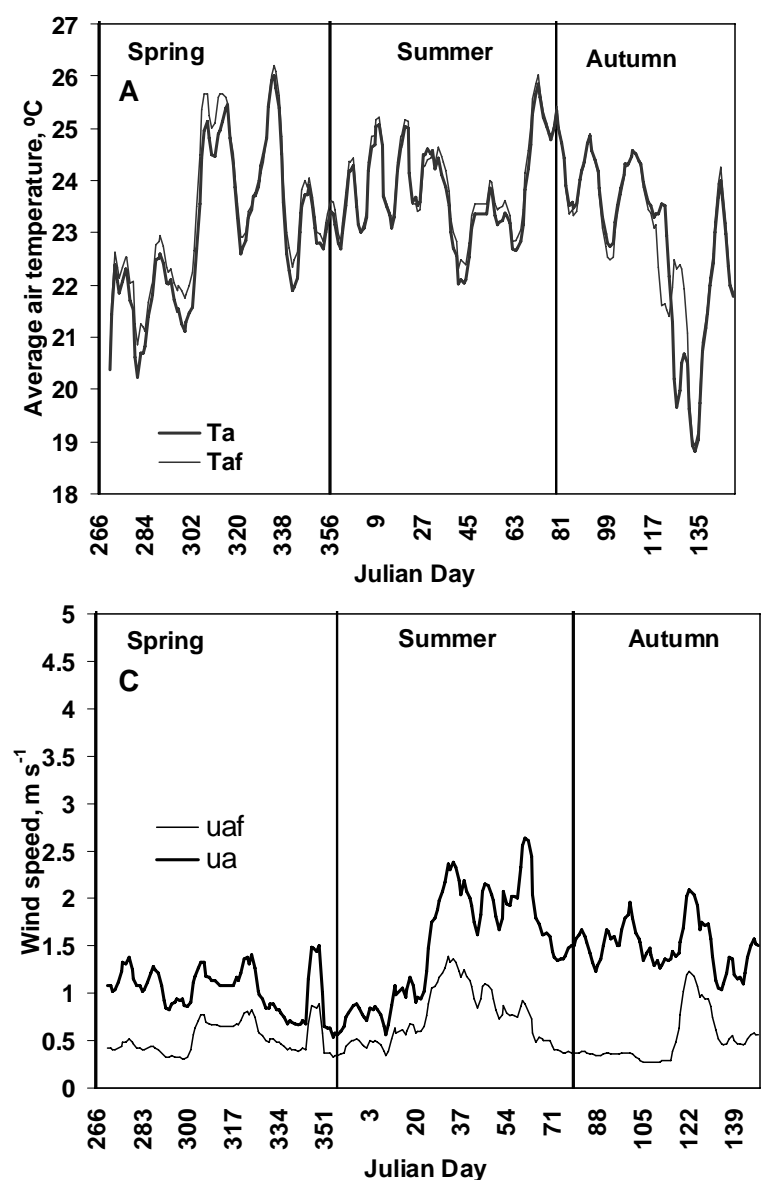
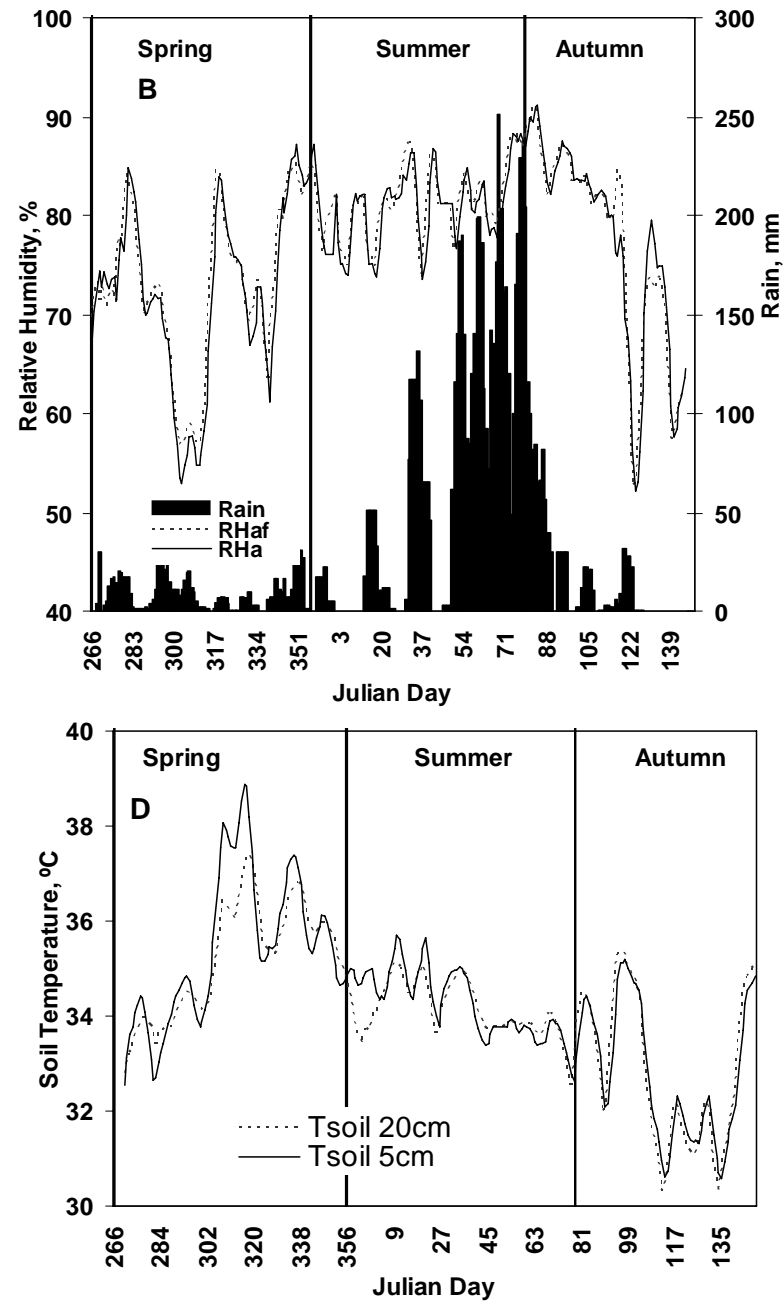

Figure 1 - Five-day moving averages of measured meteorological variables inside the canopy (3/4 of canopy height) and at the reference level (2 meters above canopy): A) Temperature, B) Relative humidity and accumulated rain, C) Wind speed, D) Soil temperature (5 and $20 \mathrm{~cm}$ below the surface).

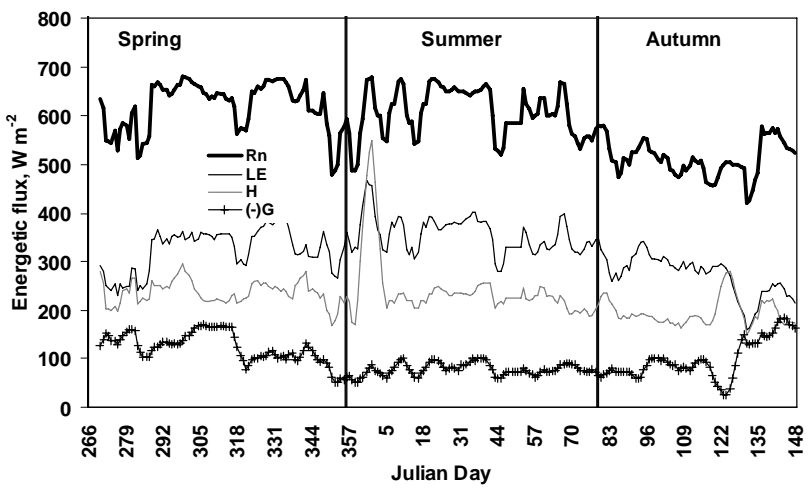

Figure 2 - Five-day moving average of maximum hourly values of energy balance components $(\mathrm{Rn}-\mathrm{Net}$ radiation, LE Latent heat flux, $\mathrm{H}$ - Sensible heat flux at the atmosphere and $\mathrm{G}$ - Sensible heat flux in the soil) estimated by the aerodynamic method.

The best meteorological variable simulated by the Deardorff (1978) model was the air temperature inside the canopy $\left(\mathrm{T}_{\mathrm{af}}\right)$. The smallest errors for all seasons were found next to midday. At other periods, the model had a tendency to underestimation, however, mean absolute differences of no more than $3^{\circ} \mathrm{C}$ were found.

As expected, the minimum hourly temperature inside the canopy always occurred between $6 \mathrm{~h} 00$ and $7 \mathrm{~h} 00$ a.m., with values around $16^{\circ} \mathrm{C}$ during spring and autumn, and around $18^{\circ} \mathrm{C}$ during summer, while the mean temperature inside the canopy remained around $27^{\circ} \mathrm{C}$ in spring, $30^{\circ} \mathrm{C}$ in summer and $28^{\circ} \mathrm{C}$ in autumn.

Deardorff's (1978) model also presented a good performance for simulating temperature at the canopy level $\left(\mathrm{T}_{\mathrm{af}}\right)$ in days with different insolation conditions. The $\mathrm{i}_{d}$ index was always higher than 0.83 , despite of some variability noticed by $\mathrm{R}^{2}$ values around 0.49 , or moreover, by the coefficient of variation $\left(\mathrm{CV}_{\mathrm{SIM}}\right)$, around $22 \%$ (Table 2).

The wind speed inside the canopy $\left(\mathrm{u}_{\mathrm{af}}\right)$, mainly in autumn, was well simulated by the model, showing that the parametrization of the wind aerodynamic profile 
for vegetated surfaces was efficient to represent field conditions. The simulated $\mathrm{u}_{\mathrm{af}}$ did not differ from the observed $\mathrm{u}_{\mathrm{af}}$, despite to the low values of $\mathrm{R}^{2}$ (Table 2), since the greatest daily mean differences found were of $0.57 \mathrm{~m} \mathrm{~s}^{-1}$ in summer, $0.51 \mathrm{~m} \mathrm{~s}^{-1}$ in autumn and a little higher in spring, reaching $0.78 \mathrm{~m} \mathrm{~s}^{-1}$. The small values of $R^{2}$ and high values of $i_{d}$, indicated that the model did not follow instantaneous variations of the wind speed but the magnitude of adjustments in subsequent moments was good. The relationships between AERO and SIM data were less significant in spring, when the sugarcane crop was in the first stages of development.

Still considering the canopy level, the last meteorological variable analyzed was the canopy relative humidity $\left(\mathrm{RH}_{\text {canoopy }}\right)$. The SIM values were not close to those found by AERO due the low values of $\mathrm{R}^{2}$, despite of the high values of $i_{d}$, and mainly, because the obtained mean differences were of $8.96 \%, 12.04 \%$ and $6.5 \%$ in the spring, summer and autumn, respectively.

For all seasons there was a high variability of AERO for 15 minute averages of relative humidity, resulting in small $\mathrm{R}^{2}$ values when compared with SIM. The model presented a tendency of underestimation

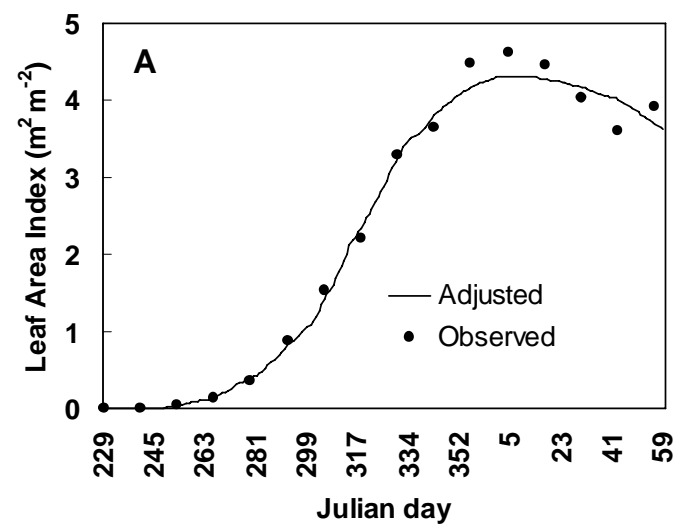

under high relative humidity, mostly before sunrise, and a tendency of overestimation under low relative humidity, close to $2 \mathrm{~h} 00 \mathrm{p} . \mathrm{m}$.

Finally, when SIM and AERO are compared for all meteorological variables when extra insolation was available in the environment, there was an increase of $\mathrm{i}_{\mathrm{d}}$ and $\mathrm{R}^{2}$ (Table 2).

In summary, high values of $i_{d}$ indicate that SIM values are close to AERO, that is, close to the 1:1 line. On the other hand, the small values of $\mathrm{R}^{2}$ indicate that SIM and AERO data often have a high dispersion. The simulations of soil water content were worse than those at the canopy level, which is related to the low capacity of the Deardorff (1978) model in simulating the soil water balance for successive days, as shown in Figure 4A.

The model was not able to simulate the drying of the soil (Figure 4), even though after long drought periods like at the end of spring and autumn, yielding different values from the AERO soil moisture. Thus, $57 \%$ of the days in spring and summer and $86 \%$ of the days in autumn, the simulated soil moisture in the root zone was above the observed values.

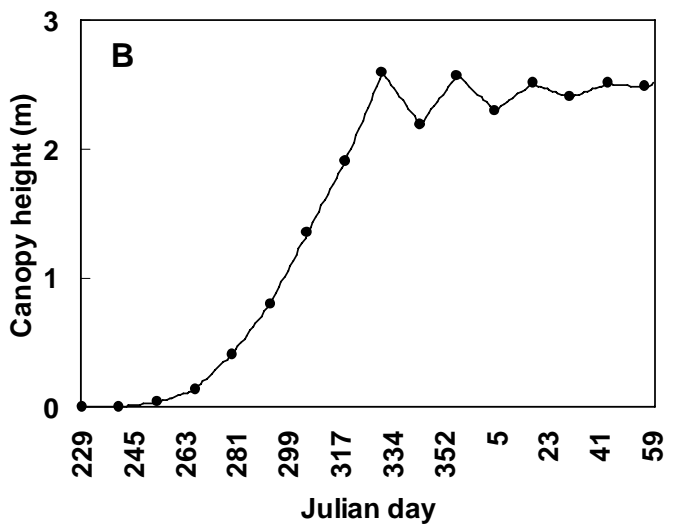

Figure 3 - A) Leaf area index variation (LAI); B) canopy height variation of the variety IAC 87-3396 of sugarcane between August 17, 2001 and May 30, 2002.
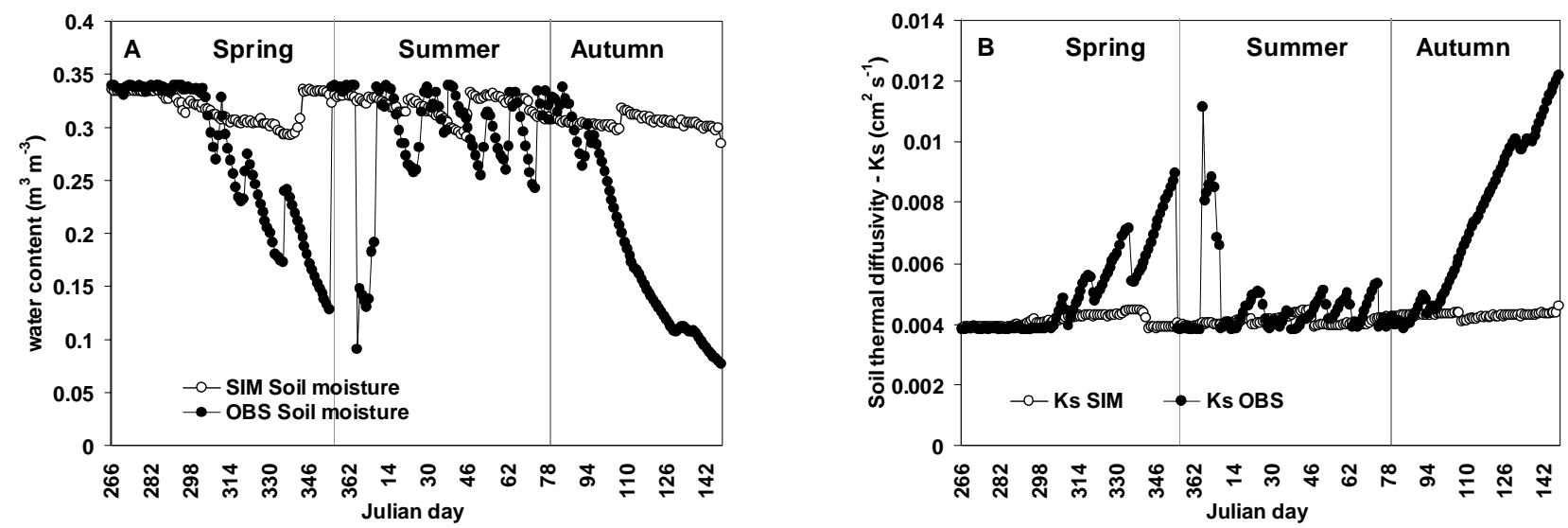

Figure 4 - Daily mean soil moisture (A) and soil thermal diffusivity (ks) (B) simulated by Deardorff's (1978) model (SIM) and calculated by the aerodynamic method (AERO) during spring, summer and autumn seasons. 


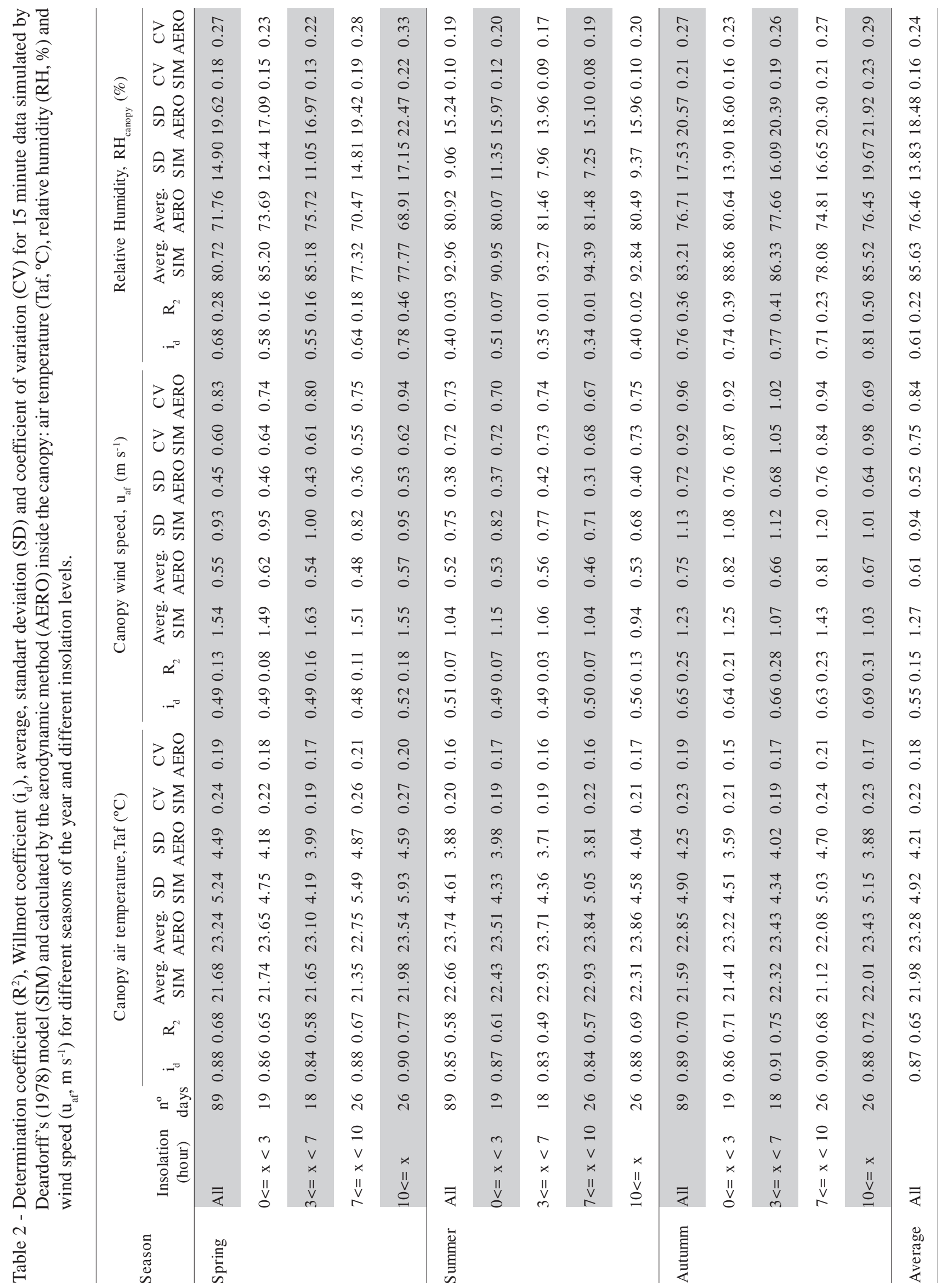


Soil moisture tends to damp the soil against sudden changes in temperature, since the heat moves from the soil to the water about 150 times easier than from the soil to the air (Brady, 1989). Therefore, if the simulated soil moisture by Deardorff's (1978) model is higher than expected, the simulated thermal capacity of this soil is also higher than the observed one. Consequently, it makes higher temperature variations in the soil more difficult, indicating that the simulated thermal difusivity (Figure 4B) of this soil may be lower as well. This supposition was confirmed by Rolim (2003), with the similar data, because the amplitude of soil temperature variations (on surface and at the $20 \mathrm{~cm}$ depth) were actually lower than the observed ones, resulting in low values of $i_{d}$ and $R^{2}$ for all seasons.

Despite these differences found between the observed meteorological elements and those simulated by Deardorff's model, one can see (Table 3) that simulations of the energy balance components - Net Radiation (Rn), Latent heat flux (LE) and Sensible heat flux at the atmosphere $(\mathrm{H})$ (Table 4) - do not present distinction in relation to the AERO fluxes during all the seasons of the year and in different insolation levels for the sugarcane crop, except the sensible heat flux in the soil (G).
Differences between Rn from AERO and the SIM data at every 15 minute interval were small, considering the high values of $i_{d}$ and $R^{2}$ for all seasons (Table 3), with exception to summer $\left(\mathrm{d}=0.79, \mathrm{R}^{2}=\right.$ $0.50)$ due to a greater nebulosity and occurrence of rain (Figure 1B), because there was as well a tendency to improve Rn estimates as the insolation availability increased (Table 3).

This similarity between AERO and SIM data of $\mathrm{Rn}$ is also due, among other reasons, to the fact that Deardorff's model made a good approach to the total albedo data of the surface (maximum values: spring $=0.34$; summer $=0.36$ and autumn $=$ 0.33 ), that directly affects the amount of radiation available in the system soil-vegetation-atmosphere (Figure 5).

Relationships between the AERO and SIM data at every 15 minute intervals of latent heat flux in the atmosphere (LE) (Table 3) and sensible heat flux in the atmosphere $(\mathrm{H})$ (Table 4) also were high, taking into account the values of $i_{d}$ found for all seasons. The lower values of $i_{d}$ during the summer were, on account of the same reasons already discussed in relation to $\mathrm{Rn}$, due to the sensibility of the Deardorf's (1978) model in relation to the available insolation.

Table 3 - Determination Coefficient $\left(\mathrm{R}^{2}\right)$, Willmott Coefficient ( $\mathrm{i}_{\mathrm{d}}$ ), average, standart deviation (SD) and Coefficient of Variation (CV) of 15 minute data simulated by Deardorff's (1978) model (SIM) and calculated by the aerodynamic method (AERO) of Net Radiation (Rn, $\mathrm{W} \mathrm{m}^{-2}$ ) and Latent Heat Flux (LE, $\mathrm{W} \mathrm{m}^{-2}$ ) in different seasons of the year and for different insolation levels.

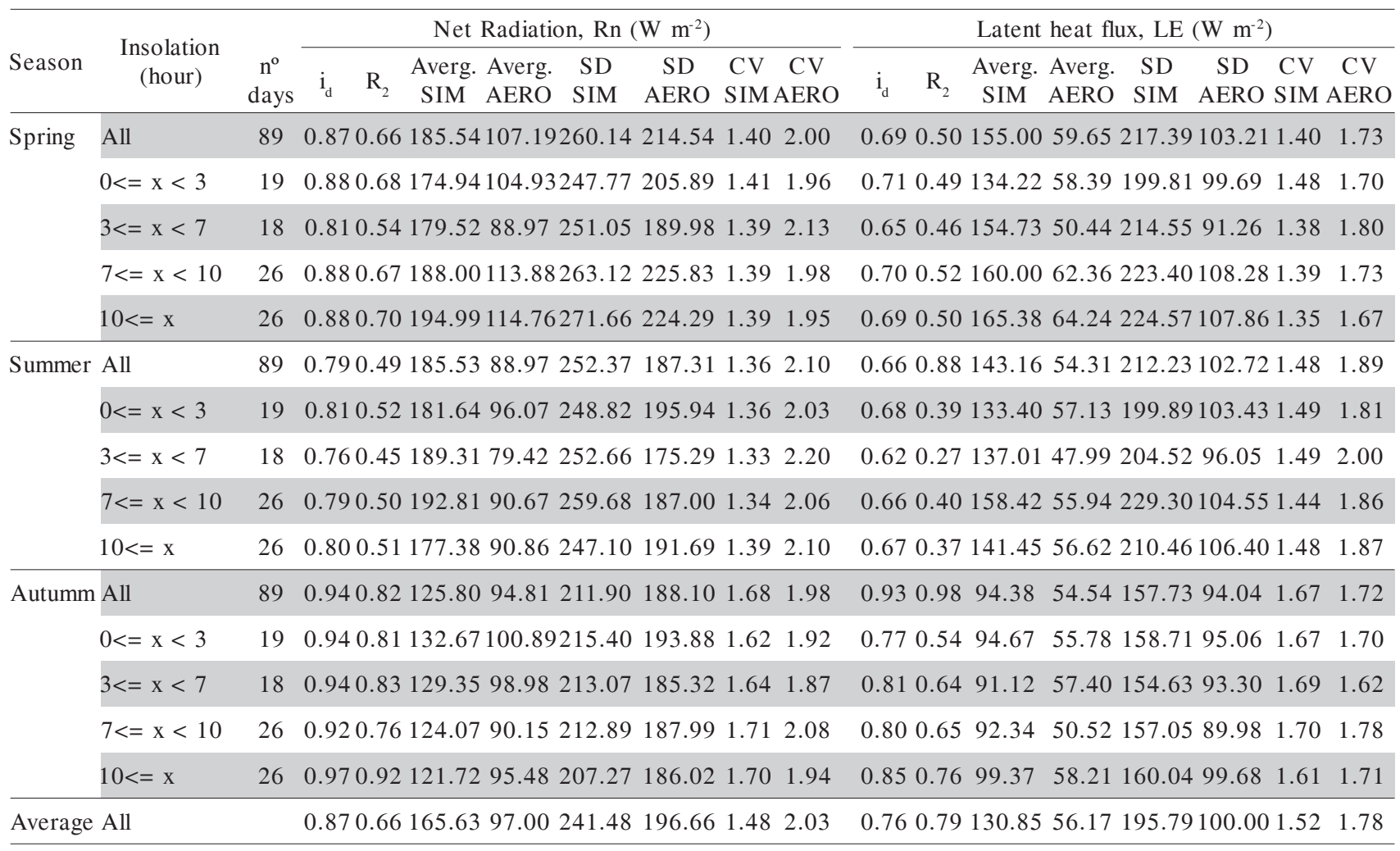


Table 4 - Determination Coefficient $\left(\mathrm{R}^{2}\right)$, Willmott Coefficient, $\left(\mathrm{i}_{\mathrm{d}}\right.$ ), Mean, standart deviation (SD) and Coefficient of Variation (CV) of 15 minute data simulated by Deardorff's (1978) model (SIM) and calculated by the aerodynamic method (AERO) for the Sensible Heat Flux $\left(\mathrm{H}, \mathrm{W} \mathrm{m}^{-2}\right)$ in the atmosphere, Sensible Heat Flux (H, W m²) in the soil (G, $\mathrm{W} \mathrm{m}^{-2}$ ) for different seasons of the year and at different insolation levels.

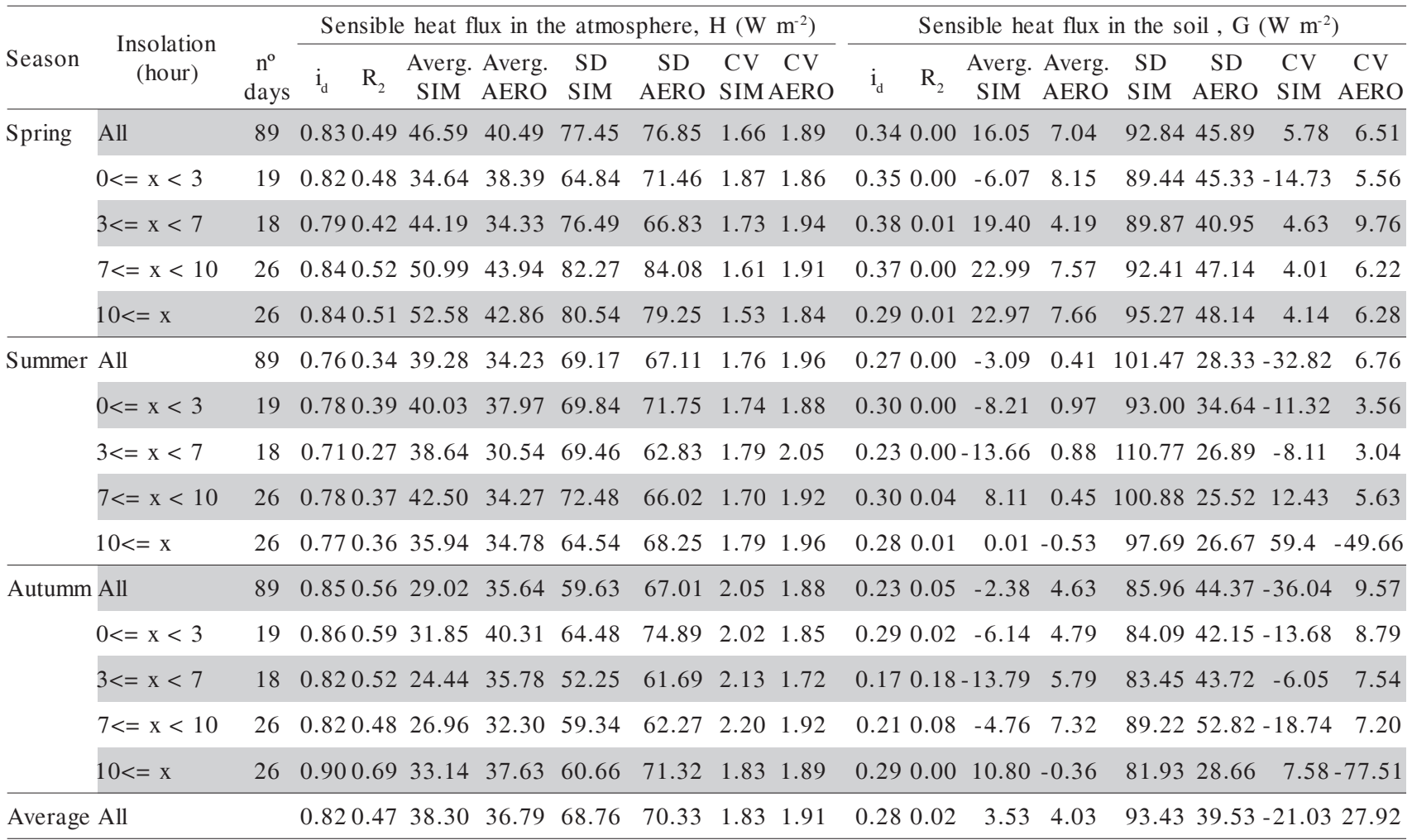
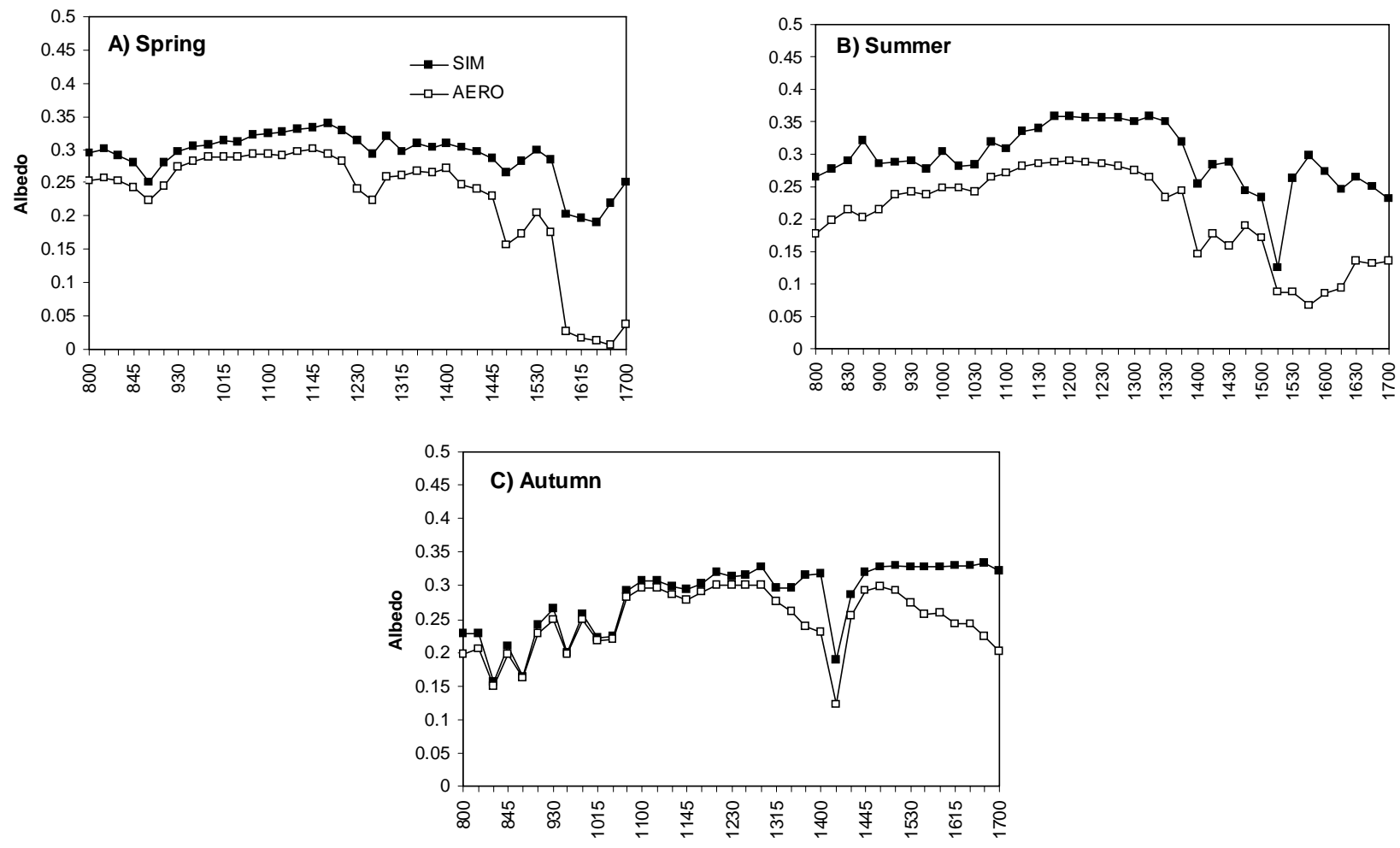

Figure 5- Hourly average albedo simulated by Deardorff (1978) model (SIM) and calculated by aerodynamic method (AERO) during spring (A), summer (B) and autumn (C) seasons. 
Finally, there was no agreement between AERO and SIM data of sensible heat fluxes in the soil (G), as verified in different seasons of the year (Table 4). This fact is a consequence of the low variation of the simulated thermal difusivity, which is a result of the low variation of the water contents in the soil profile, or in a broad way, is a result of the low capacity of the Deardorff model in simulating of the crop water budget. Despite the low relationships of G, the model could recalculate the energy balance making the estimatives of Rn, LE and H statistically close. In this way the model becomes interesting for agrometeorological purposes, since it needs only a few measured data at a reference level.

\section{CONCLUSIONS}

The latent heat flux and the sensible heat flux at the atmosphere, simulated by Deardorff's (1978) model did not presented differences in comparison to the aerodynamic method in the autumn of Piracicaba, State of São Paulo, Brazil. The greatest differences between the Deardorff (1978) model and the aerodynamic method were found in the simulations of the sensible heat flux in the soil.

\section{ACKNOWLEDGEMENTS}

To FAPESP for financial support and the Instituto Agronômico- IAC, Piracicaba for the experimental area.

\section{REFERENCES}

BHUMRALKAR, C.M. Numerical experiments on the computation of ground surface temperature in an atmospheric general circulation model. Journal of Applied Meteorology, v.14, p.1246-1258, 1975.

BRADY, N.C. Natureza e propriedades dos solos. Rio de Janeiro: Freitas Bastos, 1989. 878p.

BULL, T.A.; GLASZIOU, K.T. Sugar cane. In: EVANS, L.T. (Ed.) Crop physiology: some case histories. Cambridge: Cambridge University Press, 1975. cap.3, p.51-72.

DEARDORFF, J.W. Efficient prediction of ground surface temperature and moisture, with inclusion of a layer of vegetation. Journal of Geophysical Research, v.83, p.1889-1903, 1978.

GARRET, A.J. A parameter study of interactions between convective clouds, the convective boundary layer, and a forested surface. Monthly Weather Review, v.110, p.1041-1059, 1982.

GATES, D.M. Biophysical ecology. New York: Springer, 1980. 611p.

HEMAKUMARA, H.M.; CHANDRAPALA, L.; MOENE, A.F. Evapotranspiration fluxes over mixed vegetation areas measured from large aperture scintillometer. Agricultural Water Management, v.58, p.109-122, 2003.
LEME, E.J.A.; MANIEIRO, M.A.; GUIDOLIN, J.C. Estimativa da área foliar da cana-de-açúcar e sua relação com a produtividade. Cadernos PLANALSUCAR, n.2, p.3-9, 1984

MACHADO, E.C.; PEREIRA, A.R.; FAHL, J.I.; ARRUDA, H.V.; CIONE, J. Índices biométricos de duas variedades de cana-deaçúcar. Pesquisa Agropecuária Brasileira, v.17, p.1323-9, 1982.

MARTA, A.D.; MAGAREY, R.D.; MARTINELLI, L.; ORLANDINI, S. Leaf wetness duration in sunflower (Helianthus annuus): analysis of observations, measurements and simulations. European Journal of Agronomy, v.26, p.310-316, 2007

McCUMBER, M.C. A numerical simulation of the heat and moisture fluxes upon Mesoescale circulation. Charlottesville: University of Virginia, 1980. 255p. Thesis (PhD.).

MONTEITH, J.L.; UNSWORTH, M.H. Principles of environmental physics. New York: Elsevier, 1990. 271p.

OLIVEIRA, A.P.; SOARES, J.; ESCOBEDO, J.F. Surface energy budget: observation and modeling. In: CONGRESSO BRASILEIRO DE AGROMETEOROLOGIA, 11., Florianópolis, 1999. Anais. CD-ROM

PAUWELS, V.R.N.; VERHOEST, N.E.C.; De LANNOY, G.J.M.; GUISSARD, V.; LUCAU, C.; DEFOURNY, P. Optimization of a coupled hydrology-crop growth model through the assimilation of observed soil moisture and leaf area index values using an ensemble Kalman filter. Water Resources Research, v.43, W04421, doi:10.1029/2006WR004942, 2007.

ROLIM, G.S. Validação do modelo de Deardorff (1978) para cálculo de balanço de energia em cultura de cana-de-açúcar (Saccharum spp.). Botucatu: UNESP/FCA, 2003. 106p. Tese (Doutorado).

SHUTTLEWORTH, W.J.; WALLACE, J.S. Evaporation from sparse crops-an energy combination theory. Quarterly Journal of the Royal Meteorological Socitey, v. 111, p.839855, 1985.

SOARES, J.; OLIVEIRA, A.P.; ESCOBEDO, J.F Surface energy balance: observation and numerical modeling applied to Candiota. Air pollution and acid rain; the Candiota Program. São Paulo: Instituto de Pesquisas Meteorológicas, 1996. 149p.

TARGINO, A.C.L.; SOARES, J. Modeling surface energy fluxes for Iperó, SP, Brazil: an approach using numerical inversion. Atmospheric Research, v.63, p.101-121, 2002.

TATTARI, S.; IKONEN, J.P.; SUCKSDORFF, Y. A comparison of evapotranspiration above a barley field based on quality tested Bowen ration data and Deardorff modeling. Journal of Hydrology, v.170, p.1-14, 1995.

UNSWORTH, M.H.; MONTEITH, J.L. Aerosol and solar radiation in Britain. Quarterly Journal of the Royal Meteorology Society, v.99, p.778-797, 1972.

VILLA-NOVA, N.A.; PEREIRA, A.B.; SHOCK, C.C. Estimation of reference evapotranspiration by an energy balance approach. Journal of Agricultural Engineering Research, v.96, p.605-615, 2007.

VOGEL, C.A.; BALDOCCHI, D.D.; LUHAR, A.K.; RAO, K.S. A comparison of hierarchy of models for determining energybalance components over vegetation canopies. Journal of Applied Meteorology, v.34, p.2182-2196, 1995.

WILLMOTT, C.J. On the validation of models. Physical Geography, v.2, p.184-194, 1981.

ZAPATA, N.; MARTÍNEZ-COB, A. Evaluation of the surface renewal method to estimate wheat evapotranspiration. Agricultural Water Management, v.55, p. 141-157, 2002.

Received October 31, 2006

Accepted January 07, 2008 